\title{
A Descriptive Study of Life Syllabus in Assessing Proficiency Level and Collocational Categories of Iranian EFL Learners
}

\author{
Mustapha Hajebi \\ Department of Education, Bandar Abbas, Iran
}

\begin{abstract}
This research is done to prove the effect of life syllabus in assessing proficiency level and collocational categories of Iranian EFL learners. To this end, four hundred and twenty EFL learners from Yazd and Shiraz universities were selected. They were in intermediate and advanced proficiency groups. The participants were assigned into three groups of one hundred and forty learners and took each of the tests separately. The result appeared to manifest that learners' perception improve by advanced learners who received life syllabus instructions. It also yielded compelling reason to argue that advanced participants based on life syllabus performed more efficiently compared to their intermediate peers and indicated more collocational competence. The study suggested important implications for language learners, EFL instructors and materials developers.
\end{abstract}

Index Terms — life syllabus, collocation, language proficiency, EFL

\section{INTRODUCTION}

The framework of this research is based on Pishghadam's Applied ELT and Life Syllabus (2011). Pishghadam's paper (2011) altered view of ELT for thinking about foreign language studies and its own educational nature. Pishghadam (2011) stated that it is time to have revision in applied linguistics and ELT. So, he presented a new idea of Applied ELT into English language teaching and learning. Therefore, learning would be interesting for learners in Applied ELT as there are more interesting features that facilitate learning for them. However, applied ELT is to switch the direction, taking a more contributory role (Pishghadam, 2011). In applied ELT, discussions are over language and linguistics with issues regarding life qualities. So, it's time for ELT to engage in life-and-language classes rather than language-and-life ones (Pishghadam \& Zabihi, 2012, 2013). Applied ELT, with the purpose of sending a map as Life Syllabus for the ELT community to consider the improvement of these life skills prior to language learning was further expanded by Pishghadam and Zabihi (2012). ELT classes can therefore be suitable places for life skills training programs. ELT classes can therefore be suitable places for life skills training programs (Pishghadam \& Zabihi, 2012).

One of the main approaches to language testing is the integrative approach. It is concerned with overall meaning and proficiency, the communicative effect of discourse and the underlying linguistic competence (Oller, 1979).

Vocabulary knowledge don't consider understanding the meanings of given words in isolation, but also knowing the words that co-occur with each other. English language native speakers have thousands of words at their disposal. Theoretically, by using their knowledge of grammar, they use the words to produce and comprehend an unlimited number of sentences that they have never heard or said before. Putting words together according to their communication needs in different ways makes them to use a large number of ready-made chunks of words. When words are combined in a chunk, they have the ability to predict each other's occurrence.

This study is aimed at the effect of life syllabus in assessing proficiency level and collocational categories of Iranian EFL learners. Thus, it intends to determine whether that advanced participants based on life syllabus performed more efficiently compared to their intermediate peers and indicated more collocational competence or not.

\section{A. Collocational Competence}

Learning a language is the result of many competences grouped together; so, these competences should be developed to achieve the learning objectives. Communicative and linguistic competences are familiar expressions but "collocational competence" is usually an unfamiliar phrase. Lewis (2000) claimed most of us are acquainted with the concept of communicative competence, but we should add conception of collocational competence to our thinking.

Students have many problems in their writing assignments without using this competence. One is grammatical mistakes. Because students are willing to create longer utterances, as they do not know collocations (Hill, as cited in Michael Lewis, 2000, p. 49). Collocations are greatly different between languages and make difficulty in mastering foreign languages. Therefore, to overcome collocational problems, learners need help in the classroom. Collocational competence should be developed to overcome the problem of word associations and to get fluency and proficiency in English and also especially foreign language writing. The improvement of communicative competence would result in the development of students' collocational competence. Understanding collocations means knowing vocabulary, writing 
and speaking which helps the learner to perform better in the foreign language and that enables him/her to speak and write more efficiently. Hoey (2005) claimed that every word has a collocation use. The selection of one word will help language learner to recall its regular collocates more readily. He mentioned that, this priming is the result of the way in which a word is acquired through confrontations with it in speech and writing.

\section{B. Collocations and Second Language Teaching}

After the development of electronic corpora in the 1960s, the term collocation has been given more attention and also the combinational patterns in the English language increased. Since then, research on collocations has increased substantially. Some authors like Ellis (2001) support the idea that knowledge of language depends on collocational knowledge. Although the extensive use and importance of collocations in the language is identified by many authors (Kjellmer 1984; Nation, 2001; Stubbs 1995), not much attempts have been made to combine the collocations teaching in the English learning curriculum. Michael Lewis developed the Lexical Approach (1993), and McCarthy et al. (2006), authors of the Touchstone material include collocations in the vocabulary work. Nesselhauf (2005) studies collocations in a learner corpus and presents suggestions on selecting collocations for teaching English.

The idea of teaching a word boosts with its most common collocates and explains, for example most intermediate students understand the words hold and conversation; however they may not understand the collocation hold $a$ conversation (Hill, 2000). He also declares that vocabulary work in most classes should be to make students more collocationally competent with the words which they are already familiar. This would then be familiar language and its collocations.

Fluency is often defined on the one hand in terms of smoothness, rater of speech, pausing, hesitations and connectedness; on the other hand more fluent speakers are likely to use more lengthy utterances and to speak more (Luoma, 2004). Therefore, less fluent speakers produce slow and uneven speech with more hesitations and stumbling which can be corrected by enhancing the process of planning in speaking and paving the way for automatic retrieval of necessary vocabulary and grammar (Fulcher, 2003).

L2 learners generally pay attention to individual words and break the collocation down into separate units, which influence their fluency as they have to reconstruct the words appropriately at the time of use (Barfield, 2009; Wray, 2002). This approach which focuses on awareness-raising activities in teaching collocations was considered as an option to fill the gap in teaching collocations/ multiword units. The attention-drawing technique which is also referred to as the effectiveness of 'phrase-noticing' is related to Lewis's Lexical Approach. It has also been put to the test by Boers et al. (2006). The types of collocations that should be taught are very important and it has not been properly addressed. Collocation dictionaries which provide common collocations are useful for teachers and L2 learners.

\section{Lexical and Grammatical Collocations}

Collocations fall into two major groups: grammatical collocations and lexical collocations (Benson \& Ilson, 1997).

\section{Grammatical Collocations}

Grammatical collocations consist of a noun, an adjective, a verb plus a preposition or 'to +infinitive' or 'that-clause' and is distinguished by 8 basic kinds of collocations:

$\mathrm{G} 1=$ noun + preposition e.g. blockade against, apathy towards

$\mathrm{G} 2=$ noun + to-infinitive e.g. He was a fool to do it., They felt a need to do it.

$\mathrm{G} 3=$ noun + that-clause e.g. We reached an agreement that she would represent us in court.

$\mathrm{G} 4=$ preposition + noun e.g. by accident, in agony

G5 = adjective + preposition e.g. fond of children, hungry for news

G6= adjective + to-infinitive e.g. it was necessary to work, it's nice to be here

G7= adjective + that-clause e.g. she was afraid that she would fail, it was imperative that I be here

G8= 19 different verb patterns in English e.g. verb + to-infinitive (they began to speak), verb + bare infinitive (we must work) and other.

\section{Lexical Collocations}

Lexical collocations consist of nouns, adjectives, verbs and adverbs. They also do not contain prepositions, infinitives or relative clauses. We have 7 types of them below:

$\mathrm{L} 1=$ verb (which means creation/action) + noun/pronoun/prepositional phrase e.g. come to an agreement, launch a missile

$\mathrm{L} 2=$ verb (which means eradication/cancellation) + noun e.g. reject an appeal, crush resistance

L3 $=$ [adjective + noun] or [noun used in an attributive way + noun] e.g. strong tea, a crushing defeat, house arrest, land reform

$\mathrm{L} 4=$ noun + verb naming the activity which is performed by a designate of this noun e.g. bombs explode, bees sting

L5 = quantifier + noun e.g. a swarm of bees, a piece of advice

L6= adverb + adjective e.g. hopelessly addicted, sound asleep

L7= verb + adverb e.g. argue heatedly, apologize humbly.

\section{RESEARCH DESIGN}


This study used quantitative methods in measuring collocational competence of Iranian EFL learners.

\section{A. Participants}

The participants were 420 Persian EFL learners of English who were studying English language at Yazd and Shiraz universities. They were male and female students that their ages were between 18-24 for intermediate group and 23-32 for advanced group.

\section{B. Instruments}

Several instruments used for data collection. In this study, four types of test were utilized as measurement instruments:

First, an Oxford placement test was conducted to determine participants' collocation proficiency so as to select and include those students who scored within acceptable range of collocation proficiency in the study. Second, a 50-item collocation C-test with high validity was developed for this study. Next, a 50-item multiple-choice standard collocation cloze test was developed for this study. Finally, a 50 item collocation open ended test was developed for this study.

\section{RESUltS}

In this study, learning collocation was to provide an explanation whether these three types of test e.g. cloze test, Ctest and open ended test are effective in measuring the collocational competence of EFL learners, and which of these three tests are more effective in measuring collocational competence of learners.

A. ANOVA Results for Test Types and Proficiency Level

TABLE 3.1

DESCRIPTIVE STATISTICS OF THE TWO-WAy ANOVA REGARDING THE EFFECT OF TEST TYPE AND PROFICIENCY LEVEL ON COLLOCATIONAL SCORES Descriptive Statistics

Dependent Variable: Scores

\begin{tabular}{|ll|l|l|l|}
\hline Test_type & Proficiency_level & Mean & Std. Deviation & N \\
\hline Cloze & Intermediate & 44.06 & 7.583 & 70 \\
& Advanced & 61.23 & 10.239 & 70 \\
& Total & 52.64 & 12.443 & 140 \\
\hline C-test & Intermediate & 41.54 & 11.543 & 70 \\
& Advanced & 61.03 & 9.465 & 70 \\
& Total & 51.29 & 14.360 & 140 \\
\hline open ended test & Intermediate & 24.86 & 4.094 & 70 \\
& Advanced & 32.49 & 3.706 & 70 \\
& Total & 28.67 & 5.458 & 140 \\
\hline Total & Intermediate & 36.82 & 11.893 & 210 \\
& Advanced & 51.58 & 15.872 & 210 \\
& Total & 44.20 & 15.837 & 420 \\
\hline
\end{tabular}

TABLE 3.2

TESTS BETWEEN SUBJECTS EFFECT SHOWING THE RESUlTS OF TWO WAY ANOVA REGARDING THE EFFECT OF TEST TYPE AND PROFICIENCY LEVEL ON COLLOCATIONAL SCORES

Tests of Between-Subjects Effects

Dependent Variable: Scores

\begin{tabular}{|l|l|l|l|l|l|}
\hline Source & $\begin{array}{l}\text { Type III Sum of } \\
\text { Squares }\end{array}$ & df & Mean Square & F & Sig. \\
\hline Corrected Model & $76413.714^{\mathrm{a}}$ & 5 & 15282.743 & 220.597 & .000 \\
Intercept & 820528.800 & 1 & 820528.800 & $1.184 \mathrm{E} 4$ & .000 \\
Test_type & 50767.600 & 2 & 25383.800 & 366.400 & .000 \\
Proficiency_level & 22880.952 & 1 & 22880.952 & 330.273 & .000 \\
Test_type* Proficiency_level & 2765.162 & 2 & 1382.581 & 19.957 & .000 \\
Error & 28681.486 & 414 & 69.279 & .639 \\
Total & 925624.000 & 420 & & & \\
Corrected Total & 105095.200 & 419 & & & \\
\hline
\end{tabular}

a. R Squared $=.727$ (Adjusted R Squared $=.724)$

Test type row indicates a significance value of 0.001 , which shows that the test types can affect collocation scores. The proficiency level has also a significance value of 0.001 which shows that proficiency level affects collocation 
scores. The effect size of the test type variable, as shown under partial Eta Squared column, is .639 indicating a large effect size.

Given the significance of the test type variable, it should become clear which test type is significantly different from the other tests. Here, table called multiple comparisons should be investigated.

\section{B. MANOVA Results for Proficiency Level and Collocational Categories}

TABLE3.3

DESCRIPTIVE STATISTICS FOR PROFICIENCY LEVEL AND COLLOCATIONAL CATEGORIES Descriptive Statistics

\begin{tabular}{|ll|l|l|l|}
\hline & Proficiency_level & Mean & Std. Deviation & N \\
\hline Noun_collocation & intermediate & 40.14 & 15.969 & 210 \\
& advanced & 55.95 & 17.725 & 210 \\
& Total & 48.05 & 18.616 & 420 \\
\hline Verb_collocation & intermediate & 32.57 & 16.165 & 210 \\
& advanced & 48.43 & 18.403 & 210 \\
& Total & 40.50 & 19.034 & 420 \\
\hline Adjective_collocation & intermediate & 27.76 & 15.382 & 210 \\
& advanced & 42.57 & 21.433 & 210 \\
& Total & 35.17 & 20.053 & 420 \\
\hline Adverb_collocation & intermediate & 37.14 & 18.338 & 210 \\
& advanced & 51.52 & 25.085 & 210 \\
& Total & 44.33 & 23.096 & 420 \\
\hline Preposition_collocation & intermediate & 45.67 & 19.313 & 210 \\
& advanced & 59.29 & 20.681 & 210 \\
& Total & 52.48 & 21.116 & 420 \\
\hline
\end{tabular}

There was a statistically significant difference between intermediate and advanced learners on the combined dependent variables, $\mathrm{F}(5,414)=29.04 \mathrm{p}=.001$; Wilks' Lambda $=.740$; partial eta squared $=.26$. All of the dependent variables reached statistical significance, when the results for the dependent variables were considered separately. Noun collocation reported $\mathrm{F}(1,418)=92.2 \mathrm{p}=.001$,partial eta squared $=.181$, verb collocation reported $\mathrm{F}(1,418)=88.01$ $\mathrm{p}=.001$, partial eta squared $=.174$, adjective collocation reported $\mathrm{F}(1,418)=66.17 \mathrm{p}=.001$, partial eta squared $=.137$, adverb collocation reported $\mathrm{F}(1,418)=44.98 \mathrm{p}=.001$, partial eta squared $=.097$ and finally, prepositional collocation reported $\mathrm{F}(1,418)=48.64 \mathrm{p}=.001$, partial eta squared $=.104$. An inspection of the mean scores indicated that advanced learners reported higher collocational score in noun collocation $(\mathrm{M}=55.95, \mathrm{SD}=17.72)$ than intermediate learners $(M=40.14, S D=15.96)$, again advanced learners reported better score $(M=48.43, S D=18.40)$ in verb collocation than intermediate learners $(\mathrm{M}=32.57, \mathrm{SD}=16.16)$, advanced learners in adjective collocation showed these scores $(\mathrm{M}=42.57$, $\mathrm{SD}=21.43)$, while intermediate learners reported $(\mathrm{M}=27.76, \mathrm{SD}=15.38)$, advanced learners in adverb collocation had such scores $(\mathrm{M}=51.52, \mathrm{SD}=25.08)$ while intermediate learners reported $(\mathrm{M}=37.14, \mathrm{SD}=18.33)$, Finally, advanced learners in prepositional collocation showed $(M=59.29, S D=20.68)$ while intermediate learners reported such scores $(\mathrm{M}=45.67, \mathrm{SD}=19.31)$.

\section{CONCLUSION}

\section{A. Types of Test}

The results acquired from two-ways between groups analysis of variance on the intermediate and advanced learners' performances on the cloze test, it was indicated that advanced learners performed much better on this test having a mean score of 61.23 compared with intermediate learners which had a mean score of 44.06. So, proficiency level is an important factor for learners to answer cloze test items. The findings of this study contribute to the deeper understanding of how proficiency level can affect the learners' performance in answering cloze test items in an Iranian EFL context. Advanced proficiency group learners have already proved to be the best group in answering collocational items of cloze test. The reason for these results might be partially or wholly due to the explicit nature of cloze test which makes use of a fixed deletion technique or random deletion technique.

C-Test is another type of test that is used in measuring the reading ability of the learners. So, this test was used as to whether it can measure the collocational competence of Iranian EFL learners or not. Cloze test provides the answers and the testes need to choose one of the choices, but the learners do not have such opportunities in answering C-test and they are supposed to simply supply the needed letters which imposes heavy burden on the participants' processing capacities. Second, the C-test provides the first half of the word and there are some dashes after the first half which shows the number of letters which are required so that the word is completed. Third, too many mutilated words are 
provided that makes perceiving complete words difficult and the learners complain a lot about the readability and face validity of the tests. Finally, the mechanics and rules of writing help the learner in recognizing different collocational categories and answering test items like comma, colon, semicolon and etc.

Open ended test done in order to enable the test designer to compare the results between these three test types fairly. In this test type, the learners are supposed to provide the answers themselves. From the findings of this study, these conclusions can be drawn. First, although all of these test types have been constructed based on similar passages, but this test type was deemed as the most difficult one among all the three test types. The participants had to answer and fill the blanks using the environment and context of the test. Unlike the other test types, the learners were given no clue in answering test items. Second, in this test type, advanced proficiency learners who received life syllabus scored better than their intermediate peers. This indicates that proficiency plays a major role and advanced learners which had previous opportunity in facing and dealing with these texts and collocations items performed more effectively on this test. Finally, another point that needs to be mentioned is that as there was not sufficient clue and context in this test for test takers, they were not that interested in answering items as it required heavy processing capacity on the part of language learners while in the other two test types, the learners had some clue.

\section{B. Collocation}

The five collocational categories of noun, verb, adjective, adverb and preposition are chosen to be further investigated in EFL learners' performances. Each of these three test types had fifty items and each of these tests had ten noun, verb, adjective, adverb and prepositional collocations.

The findings of this study led to the following conclusions. First, cloze test has measured noun, verb, adjective and adverb collocations better than C-test and open ended tests which may be related to the point that cloze test provides four choices for each item and the learners are supposed to choose among them. Second, C-test has been more effective in measuring prepositional collocations of the participants as half of the prepositional words are provided and this serves as a big clue for language learners. Third, in case of open ended test, as participants had no clue and no choice is provided for them, they performed poorly on this test through all the five collocational categories in comparison to the other two tests. Finally, it was shown that participants' performance on all the three test types through all the collocational categories were significant. $(p=.001)$.

These findings are in line with some of the research projects which have been conducted in this regard. These findings support this view point that different proficiency levels influence the learners' performances on lexical and collocational categories, and higher proficiency levels with life syllabus learners can perform far more effectively on these categories.

This study tried to utilize the lexical and grammatical collocations framework in assessing Iranian EFL learners' collocational competence. On the whole, the results of the conducted analyses suggested that C-test was not superior to cloze test and open ended test in assessing collocational competence of EFL learners. In addition, the analyses confirmed that proficiency level is an important and determining factor and influences participants' performances on different test types. Therefore, the learners from higher proficiency levels who received life syllabus instructions performed more effectively on different test types compared with their lower proficiency peers.

\section{Implications of the Study}

There are certain pedagogical implications based on the results of the present study. The findings of the present study may have major implications for language learners, language teaching methodology, EFL instructors, teacher trainers, syllabus designers and materials developers. Furthermore, in particular of restricted collocations, teacher's experiences show that Iranian EFL learners usually don't have adequate knowledge of English collocations. The findings of the present study suggest that test designers should develop and validate collocation tests using both grammatical and lexical collocations. The results also refer to designing tests that focus on various types of collocations. The results of this study provide more effective methods for learning collocations.

\section{Suggestions for Further Research}

The process, results and conclusion of the present study lead to some further lines of research of all, other studies can be done with the same objectives and aims in other levels. This study focused on intermediate and advanced students. It would be valuable to study knowledge of collocations at different proficiency levels, especially at the beginning level. Furthermore, to conduct a similar study, researchers can use qualitative methods for observing EFL learners' subtle progress and also their reactions to collocations and collocation instruction.

\section{REFERENCES}

[1] Aitken, K. G. (1977). Using cloze procedure as an overall language proficiency test. TESOL Quarterly, 11(1), 5967.

[2] Alderson, J.C.(1979). "The effect on the Cloze test of changes in deletion frequency," Journal of Research in Reading, (2),10818.

[3] Alonso Ramos, M., Wanner, L., Vázquez, N., Vincze, O., Mosqueira, E., \& Prieto, S. (2010a). Tagging collocations for learners. In S. Granger, M. Paquot (Eds.), eLexicograpy in the 21st century: New Challenges, New Applications. Proceedings of eLex 2009, Cahiers du Cental 7, Louvain-la-Neuve, Presses universitaires de Louvain, 369-374. 
[4] Alonso Ramos, M., Wanner, L., Vincze, O., Casamayor, G., Vázquez, N., Mosqueira, E., \& Prieto, S. (2010b). Towards a Motivated Annotation Schema of Collocation Errors in Learner Corpora. In 7th International Conference on Language Resources and Evaluation (LREC), La Valetta, Malta, 3209-3214.

[5] Cohen, A. D. (1984). "On taking tests: what the students report," Language Testing (1), 70-81.

[6] Durrant, P., Schmitt, N. (2009). To what extent do native and non-native writers make use of collocations. International Review in Applied Linguistics Language Teaching, 47, 157-177.

[7] Granger, S. (1998). Prefabricated patterns in advanced EFL writing: Collocations and formulae. In A. P. Cowie (Ed.) Phraseology. Theory, Analysis, and Applications. Oxford, Clarendon Press, 145-160.

[8] Heaton, J.B. (1990). Writing English Language Tests. London: Longman.

[9] Huang, L. (2007). Knowledge of English Collocations: An Analysis of Taiwanese EFL Learners. In C. Luke and B. Rubrecht (Eds.), Texas Papers in Foreign Language Education: Selected Proceedings from the Texas Foreign Language Education Conference (pp. 113-132). Texas: Texas University, Austins.

[10] Irvine, P., Attai, P., \&Oller, J.W. (1974). "Cloze, dictation, and the Test of English as a Foreign Language," Language Learning, 24, 245-52.

[11] Jacendoff, R. (Ed.). (1995). The boundaries of the lexicon. Hillsdale, NJ: Lawrence Erlbaum Associates, Inc.

[12] Jafapur, A. (1995). Is C-Test superior to cloze? Language Testing, 12 (2), 194-216.

[13] Khodadady, E. (2007). Knowledge of recently taught words and listening comprehension ability. Paper presented at the annual TESL Niagara Conference, Welland, Canada.

[14] Kobayashi, M. (2002). Cloze test revisited: exploring item characteristics with special attention to scoring methods. The Modern Language Journal 86, 571-86.

[15] Oller, J.W. (1973). "Cloze tests of second language proficiency and what they measure," Language Learning, 23,101-105.

[16] Oller, J.W. (1979). Language tests at school: a pragmatic approach. London: Longman.

[17] Pishghadam, R. (2011). Introducing Applied ELT as a new approach in second/foreign language studies. Iranian EFL Journal, 7(2), 8-14.

[18] Pishghadam, R., \&Ghahari, S. (2012). Life-wise language learning textbooks: Construction and validation of an emotional abilities scale through Rasch modeling. Issues in Language Teaching, 1, 1-32

[19] Pishghadam, R., \&Zabihi, R. (2012).Establishing a life-language model of proficiency: A new challenge for language testers. Iranian Journal of Language Testing, 2(2), 93-108.

[20] Pishghadam, R., \&Zabihi, R. (2013).Introducing and Exemplifying English for Life Purposes (ELP) as a new Concept in English Language Teaching. Humanizing Language Teaching, 15(3), 1-19.

[21] Pishghadam, R., Zabihi, R., \&Norouz Kermanshahi, P. (2012). Educational language teaching: A new movement beyond reflective/critical teaching. Life Science Journal, 9(1), 892-899.

[22] Rouhani, M. (2008). Another look at the C-Test: A validation study with Iranian EFL learners. The Asian EFL Journal, 10(1), 154-180.

[23] Shokouhi, H., \&Mirsalari, GH. (2010). Collocational Knowledge versus General Linguistic Knowledge among Iranian EFL Learners. Teaching English as a Second or foreign language. 13(4), 1-24 http://teslej.org/pdf/ej52/a7.pdf (September 16, 2010).

[24] Siyanova, A., \& Schmitt, N. (2008). L2 Learner production and processing of collocation: a multi-study perspective. The Canadian Modern Language Review, 64, 3, 429-458.

[25] Stubbs, J. B., \& Tucker, G. R. (1974). The cloze test as a measure of English proficiency. Modern Language Journal, 58(5-6), 239-241.

[26] Taylor, W. L. (1953). Cloze procedure: A new tool for measuring readability. Journalism Quarterly, 30, 415-453.

[27] Zarei, A., \&Koosha, M. (2003). Patterns of Iranian Advanced Learners' Problems with English Collocations: A Focus on Lexical Collocations, Iranian Journal of Applied Linguistics, 6 (1), 137-169.

Mustapha Hajebi is an English language teacher in Department of Education, Bandar Abbas, Iran. He finished his undergraduate studies at Tehran University for Teacher Education, majoring in TEFL. He continued his graduate studies at Islamic Azad University of Bandar Abbas, where he got his M.A degree in TEFL. His research interests include Second Language Teaching, Applied ELT, Speaking, Collocations and Educational Technology. 